\title{
Assessment of waterlogging induced physio- biochemical changes in sugarcane varieties and its association with waterlogging tolerance
}

\begin{tabular}{l} 
Paper received: 14.04 .2018 \\
\hline Authors Info \\
S. Singh', S.P. Singh ${ }^{1 *}$, \\
A.D. Pathak' and N. Pandey ${ }^{2}$ \\
'Division of Plant Physiology and \\
Biochemistry, ICAR- Indian \\
Institute of Sugarcane Research, \\
Lucknow- 226 002, India \\
'Department of Botany, \\
University of Lucknow, \\
Lucknow- 226 007, India \\
sps.nduat@gmail.com
\end{tabular}

\section{Edited by \\ Dr. Sumati Gaumat}

Reviewed by

Dr. R.B. Raizada

Dr. Naba Kumar Mondal
Revised received: 02.08 .2018

Accepted: 25.09 .2018
Abstract

Aim : The aim of the present investigation was to study the effect of waterlogging on growth and physiological behaviour of sugarcane varieties, and to evaluate these in relation to waterlogging tolerance to identify reliable physiological parameters for screening sugarcane genotypes for waterlogging tolerance.

Methodology : Ten sugarcane varieties including four tolerant and one sensitive were planted under waterlogged and non waterlogged (control) conditions. Waterlogging was imposed for 70 days at the crop age of 120 days, thereafter water was completely drained. Based on relative cane weight $(\%$ waterlogged/control), the ranking of varieties was done for waterlogging tolerance. Changes in cane weight, stalk growth rate, internode length, chlorophyll stability index and antioxidant enzyme activity were measured at the end of waterlogging. Leaf samples were analysed for nitrogen, phosphorus and potassium content. Correlation between waterlogging tolerance and different traits was assessed.

Results : Based on relative cane weight (\% waterlogged/control), CoLk 94184 was found to be the most waterlogging tolerant variety while CoJ 64 the most sensitive. Waterlogging remarkably reduced stalk growth rate and a significant positive correlation was found between waterlogging tolerance and stalk growth rate during waterlogging. The average internode length of sugarcane varieties increased by $11 \%$ in waterlogging as compared to control. Tolerant varieties had high chlorophyll stability index than sensitive one showing that tolerant varieties had less chlorosis in waterlogging.

Ranking of sugarcane varieties for waterlogging tolerance

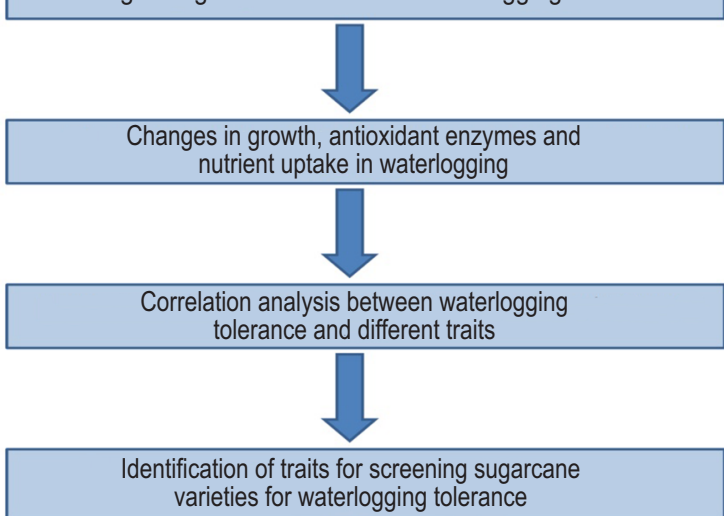

Waterlogging caused a significant increase in antioxidant enzyme activity of catalase, peroxidase and superoxide dismutase, however these increase were higher in tolerant varieties. Waterlogging induced severe deficiencies of $\mathrm{N}, \mathrm{P}$ and $\mathrm{K}$ in sugarcane; the leaf $\mathrm{N}$ and $\mathrm{K}$ concentration were below critical deficiency level. Astrong positive correlation was found between leaf $\mathrm{K}$ content and waterlogging tolerance.

Interpretation : Stalk growth rate, chlorophyll stability index and leaf potassium concentration during waterlogging were identified as efficient physiological traits for screening the sugarcane varieties for waterlogging tolerance.

Key words: Antioxidantenzymes, Chlorophyll stability index, Stalk growth rate, Waterlogging tolerance

How to cite : Singh, S., S.P. Singh, A.D. Pathak and N. Pandey : Assessment of waterlogging induced physio-biochemical changes in sugarcane varieties and its association with waterlogging tolerance. J. Environ. Biol., 40, 384-392 (2019). 


\section{Introduction}

Sugarcane is an important cash crop in the world. It faces different vagaries of nature including biotic/abiotic stress during its active growth phases. Waterlogging or excess water is one of the abiotic stresses and a widespread phenomenon that drastically reduces the growth and survival of sugarcane which may cause $18-64 \%$ reduction in cane yield depending upon the genotypes, environmental conditions, stage of development and stress duration (Gilbert et al., 2008; Glaz and Lingle, 2012). Sugarcane crop is most susceptible to waterlogging in the first 3-4 months, comparatively tolerant at 5-9 months age and hastens early maturity at later stages of stress (Gomathi et al., 2015). A soil is considered to be waterlogged when the water table rises to such an extent that the root zone becomes saturated with water, diffusion of air is curtailed and amount of oxygen is reduced with increase in $\mathrm{CO}_{2}$ partial pressure (Jackson and Drew, 1984; Greenway et al., 2006).

In India, physical degradation of soil due to waterlogging has been estimated about 11.60 million ha in which $10-30 \%$ of area comes under sugarcane cultivation, i.e., major constraint affecting productivity (Gomathi et al., 2015). In India, 73\% of the annual rainfall is received by the southwest monsoon during June to September which is the primary cause for floods and waterlogging problems. A considerable area under sugarcane crop in several parts of India are exposed to stagnant water for 2-3 months during monsoon season. The important biological consequence of waterlogging is the deficiency (hypoxia) or complete absence (anoxia) of oxygen, increase in $\mathrm{CO}_{2}$, methane and ethylene concentration and imbalance in inorganic nutrients in the soil environment which restricts the growth and development of crop (Zeng et al., 2013). Higher rate of stalk mortality, low relative growth rate, reduced cane yield, poor juice quality and sugar recovery are the major effects of waterlogging (Gomathi et al., 2015; Viator et al., 2012). Sugarcane evolve diverse adaptive strategies to cope with waterlogging stress. These mechanisms / traits which range from cellular level to whole plant level are complex and interrelated.

A shift in respiratory metabolism from aerobic to anaerobic pathways is one of the main effects of oxygen deficiency caused during waterlogging. Sugarcane adapt to anoxia during flooding by developing adventitious roots with well developed aerenchyma to assist the maintenance of root activity and supply of required oxygen (Begum et al., 2013; Jaiphong et al., 2016). The physiological changes during waterlogging may include decreased stomatal conductance and intercellular $\mathrm{CO}_{2}$ concentration, decreased rate of photosynthesis presumably due to the reduction in effective leaf area, lower crop growth rate and higher respiration rate of submerged plant organs (Hidaka and Karim, 2007; Viator et al., 2012; Jaiphong et al., 2017). Waterlogging generates oxidative stress and promotes the production of reactive oxygen species including superoxide, singlet oxygen, hydroxyl anion and hydrogen peroxide which can be detrimental to proteins, lipids and nucleic acids (Garnczarska et al., 2004). Increased activity of antioxidant enzymes and levels of antioxidant metabolites have been correlated with tolerance to wide varieties of environmental stress. Nutrient uptake is badly affected under waterlogging; the availability of major elements like N, P, K, Ca and Mg decreases while elements like Fe, Mn and Al increases in the plant above critical toxicity limit (Gilbert et al., 2007; Singh and Setter, 2017). Waterlogging induced nutrient deficiency/toxicity adversely affects physiological processes like photosynthesis, respiration and growth, causing chlorosis and necrosis and ultimately death of plant (Dodd et al., 2013; BaileySerres and Colmer, 2008). It is suggested that waterlogging tolerance is often a product of tolerance to anaerobiosis and to element deficiencies and toxicities (Setter et al., 2004). The key to progress towards evolving waterlogging tolerance sugarcane varieties is characterization of waterlogging adaptive mechanisms / traits. The objective of this study was to assess the variation for waterlogging tolerance among sugarcane varieties; and to analyse and interpret the variation in different physiological traits between tolerant and susceptible varieties to identify the screening indices for waterlogging tolerance.

\section{Materials and Methods}

Plant material and growth conditions: The present experiment was conducted at experimental farm of ICAR- Indian Institute of Sugarcane Research, Lucknow during spring season 2016. Ten sugarcane varieties including four waterlogging tolerant; CoLk 94184, BO 91, CoS 767 and UP 9530, one waterlogging sensitive; CoJ 64 and five other varieties; CoLk 12204, CoLk 07201, CoLk 12202, CoLk 12206 and CoS 97264 were evaluated under waterlogged and non-waterlogged (control) conditions in a randomized block design (RBD) with three replications. Each variety was planted in two rows of $10 \mathrm{~m}$ length with a spacing of 75 cm between rows. Full dose of phosphorus @ $80 \mathrm{~kg} \mathrm{P}_{2} \mathrm{O}_{5} \mathrm{ha}^{-1}$, potassium @ $80 \mathrm{~kg} \mathrm{~K}_{2} \mathrm{Oha}{ }^{-1}$ and $1 / 3^{\text {rd }}$ of nitrogen of full dose of 150 $\mathrm{kg} \mathrm{ha}^{-1}$ were applied at the time of planting. Rest $2 / 3^{\text {rd }}$ of nitrogen in the form of urea was top dressed in two equal splits before earthing up in the month of May and June. The crop was grown in a deep plot and waterlogging treatment was imposed by ponding $90 \mathrm{~cm}$ water above soil surface for a period of 70 days at the plant age of 120 days. Thereafter, ponded water was completely removed and no water stagnation was allowed in the plot. At this time, the non waterlogging (control) treatment received normal irrigation.

Cane weight and waterlogging tolerance : Cane weight per clump was measured in both non-waterlogged (control) and waterlogged treatments. Waterlogging tolerance of varieties was determined by using the formula, (Cane weight per clumpwaterlogged / Cane weight per clump-non waterlogged) x 100 . The varieties used in the experiment were ranked for waterlogging tolerance.

Stalk growth rate and internode length: The plant height was measured before and at the end of waterlogging, and stalk growth rate $(\mathrm{mm}$ per day) was computed. The internode length was 
determined by dividing the main shoot height with the total number of internodes.

Chlorophyll stability index: Total chlorophyll content was determined in the fresh leaves by the method of Arnon (1949) and chlorophyll stability index percent (CSI\%) was worked out by the following formula: [(total chlorophyll-waterlogged / total chlorophyllnon waterlogged) X 100].

Antioxidant enzymes assay: Antioxidant enzyme assay was performed by homogenizing $2 \mathrm{~g}$ of leaf material in $10 \mathrm{ml}$ of respective extraction buffer in a pre-chilled mortar and pestle. The homogenate was filtered and centrifuged at 20,000 xg for $20 \mathrm{~min}$ at $4^{\circ} \mathrm{C}$, collected supernatant was used as a preparatory enzyme extract. Protein concentration of the enzyme extract was estimated by following the method of Bradford (1976). Catalase (CAT) activity was measured according to Beers and Sizer (1952) and expressed as micromoles of $\mathrm{H}_{2} \mathrm{O}_{2} \mathrm{~min}^{-1} \mathrm{mg}^{-1}$ protein. The peroxidase (POX) activity was estimated by the method of Siegel and Galston (1976) and expressed in micromoles of $\mathrm{H}_{2} \mathrm{O}_{2}$ min $^{-1}$ $\mathrm{mg}^{-1}$ protein using the extinction coefficient as $26.6 \mathrm{mM}^{-1} \mathrm{~cm}^{-1}$ at $470 \mathrm{~nm}$. Superoxide dismutase (SOD) was assayed by monitoring the inhibition of photochemical reduction of nitroblue tetrazolium (NBT) by the method of Beyer and Fridovich (1987). One unit of SOD activity was defined as the amount of enzyme required to cause $50 \%$ inhibition in the reduction of NBT, as monitored at $560 \mathrm{~nm}$, under assay conditions.

Elemental analysis: Leaf samples for element analysis were collected at the end of waterlogging. Collected leaves were washed, oven dried, grinded and digested using sulphuric and perchloric acid. Leaf nitrogen concentration in digested leaf samples was estimated by the method of Linder (1944). The method of Fiske and Subba Row (1925) was used to estimate the phosphorus content whereas potassium was estimated by flame photometer.

Statistical analysis: The data were analyzed using randomized block design based on factorial experiment and mean comparison was done using least significant difference test (Gomez and Gomez, 1984).

\section{Results and Discussion}

Waterlogging significantly reduced the cane weight of sugarcane varieties (Table 2). The reduction in cane weight among sugarcane varieties due to waterlogging ranged from $12 \%$ (CoLk 94184) to $41 \%$ (CoJ 64). The average cane weight (across varieties) decreased by $27 \%$ in waterlogging relative to control. Based on relative cane weight ( $\%$ waterlogged/control), the varieties were ranked for waterlogging tolerance. The waterlogging tolerance of varieties followed the sequence: CoLk $94184>$ UP $9530>$ BO $91>$ CoLk $12202>$ CoS $767>$ CoLk 12206 > CoLk 7201 > CoLk 12204 > CoS 97264 > CoJ 64. Reduction in cane yield due to waterlogging may be attributed to decrease in photosynthesis, root development, leaf area, tiller production, stalk mortality, reduced crop growth rate, imbalance plant nutrition, lodging and cane breakage (Jiaphong et al., 2017; Gomathi et al., 2015; Viator et al., 2012). Similar to our findings, the decrease in cane weight after waterlogging has been reported earlier (Manoharan et al., 1990). In the present study, CoLk 94184, UP 9530 and BO 91 were found relatively more tolerant than other varieties and CoJ 64 was identified as most sensitive; the waterlogging tolerance and sensitivity of these varieties have been documented previously (Solomon et al., 2014; Srivastava, 2000; Dwivedi, 2000).

The stalk growth rate was reduced by $3.3 \%$ (UP 9530) to $22.3 \%$ (CoJ 64) under waterlogging over control. The significant mean square for waterlogging $x$ variety showed that varieties differed in their response to waterlogging (Table 1). The tolerant varieties had comparatively less reduction in stalk growth rate in waterlogging as compared to sensitive ones. A significant correlation ( $r=0.837$, Table 3 ) was found between waterlogging tolerance and stalk growth rate during waterlogging. This suggest that stalk growth rate can be an important selection indices for screening the varieties for waterlogging tolerance. The higher growth rate characteristics of a variety during waterlogging indicates that it is equipped with certain mechanisms that helps it to perform better under waterlogged condition. This is evident from the data of present study which shows that varieties with higher stalk growth rate have high CSI value and maintain better level of leaf tissue N, P and K content during waterlogging (Fig. 2).

Table 1: Summary of analysis of variance for different physiological characters based on variety and waterlogging treatments

\begin{tabular}{|c|c|c|c|c|c|c|c|c|c|c|}
\hline \multirow{2}{*}{$\begin{array}{l}\text { Source of } \\
\text { variation }\end{array}$} & \multirow[t]{2}{*}{ d.f. } & \multicolumn{9}{|c|}{ Mean square } \\
\hline & & $\begin{array}{l}\text { Cane weight } \\
\text { (Kg/clump) }\end{array}$ & $\begin{array}{l}\text { Stalk growth } \\
\text { rate }(\mathrm{mm} / \text { day })\end{array}$ & $\begin{array}{l}\text { Internode } \\
\text { length }(\mathrm{cm})\end{array}$ & Catalase & Peroxidase & $\begin{array}{l}\text { Superoxide } \\
\text { dismutase }\end{array}$ & Leaf $N(\%)$ & Leaf P (\%) & Leaf K (\%) \\
\hline Waterlogging & 1 & $8.385^{\star \star}$ & $34.641^{* *}$ & $43.725^{\star *}$ & $23.613^{* *}$ & $33.570^{* *}$ & $0.166^{\star *}$ & $15.040^{* *}$ & $0.216^{* *}$ & $11.249^{* *}$ \\
\hline Variety & 9 & $1.581^{* *}$ & $9.297^{\star *}$ & $10.465^{* *}$ & $0.297 \mathrm{NS}$ & 0.052 NS & $0.005^{*}$ & $0.215^{\star *}$ & $0.009^{* *}$ & $0.284^{* *}$ \\
\hline $\begin{array}{l}\text { Waterlogging } \\
\text { x Variety }\end{array}$ & 9 & 0.046 NS & $7.467^{* *}$ & $11.551^{* *}$ & $0.348^{*}$ & $0.615^{\star *}$ & $0.006^{*}$ & 0.034 NS & $0.003^{* *}$ & $0.076^{* *}$ \\
\hline Error & 38 & 0.081 & 1.265 & 1.045 & 0.145 & 0.099 & 0.002 & 0.029 & 0.001 & 0.017 \\
\hline
\end{tabular}

*,** significance at $5 \%$ and $1 \%$ levels of probability; NS: non-significant 
Table 2 : Cane weight (after waterlogging) and waterlogging tolerance (\% waterlogged/control cane weight) of ten sugarcane varieties (waterlogging duration, 70 days; crop age, 120 days)

\begin{tabular}{llll}
\hline Varieties & \multicolumn{2}{c}{ Cane weight (Kg/clump) } & \multicolumn{1}{l}{$\begin{array}{l}\text { Waterlogging tolerance } \\
\text { (\% waterlogged/control) }\end{array}$} \\
\cline { 2 - 4 } & Control & Waterlogged & $88(1)$ \\
\hline CoLk94184 & $3.52 \pm 0.27$ & $3.10 \pm 0.17$ & $80(3)$ \\
BO91 & $3.33 \pm 0.19$ & $2.66 \pm 0.28$ & $77(5)$ \\
CoS767 & $2.86 \pm 0.09$ & $2.20 \pm 0.07$ & $59(10)$ \\
CoJ64 & $2.46 \pm 0.23$ & $1.45 \pm 0.11$ & $67(8)$ \\
CoLk12204 & $2.60 \pm 0.10$ & $1.74 \pm 0.14$ & $68(7)$ \\
CoLk07201 & $2.82 \pm 0.10$ & $1.92 \pm 0.10$ & $79(4)$ \\
CoLk12202 & $3.02 \pm 0.17$ & $2.39 \pm 0.13$ & $71(6)$ \\
CoLk12206 & $2.80 \pm 0.15$ & $1.99 \pm 0.15$ & $62(9)$ \\
CoS97264 & $2.35 \pm 0.10$ & $1.46 \pm 0.09$ & $83(2)$ \\
UP9530 & $3.64 \pm 0.23$ & $3.02 \pm 0.26$ & \\
\hline
\end{tabular}

Values in parentheses indicate ranking of varieties for waterlogging tolerance. Data are mean of three replicates $( \pm$ S.E.)

Table 3: Correlation between waterlogging tolerance (\% waterlogged/control cane weight) and different physiological characters recorded under waterlogging treatment

\begin{tabular}{|c|c|c|c|c|c|c|c|c|c|c|}
\hline Characters & $\begin{array}{l}\text { Waterlogging } \\
\text { tolerance }\end{array}$ & $\begin{array}{l}\text { Stalk growth } \\
\text { rate }\end{array}$ & $\begin{array}{l}\text { Chlorophyll } \\
\text { stability index }\end{array}$ & $\begin{array}{l}\text { Internode } \\
\text { length }\end{array}$ & SOD & POX & CAT & Leaf $\mathrm{K}$ & Leaf $P$ & Leaf $\mathrm{N}$ \\
\hline $\begin{array}{l}\text { Waterlogging } \\
\text { tolerance }\end{array}$ & 1.000 & $0.840^{*}$ & $0.817^{*}$ & 0.538 & 0.486 & 0.453 & 0.488 & $0.897^{*}$ & 0.530 & 0.496 \\
\hline Stalk growth rate & & 1.000 & 0.601 & 0.316 & 0.377 & 0.478 & 0.588 & 0.615 & 0.431 & 0.066 \\
\hline $\begin{array}{l}\text { Chlorophyll } \\
\text { stability index }\end{array}$ & & & 1.000 & 0.351 & 0.536 & 0.185 & 0.189 & $0.833^{*}$ & 0.342 & 0.416 \\
\hline Internode length & & & & 1.000 & 0.178 & 0.481 & 0.173 & 0.615 & 0.480 & $0.683^{*}$ \\
\hline SOD & & & & & 1.000 & -0.072 & -0.094 & 0.297 & 0.565 & 0.054 \\
\hline POX & & & & & & 1.000 & 0.408 & 0.568 & 0.182 & 0.107 \\
\hline CAT & & & & & & & 1.000 & 0.352 & -0.242 & 0.027 \\
\hline Leaf $K$ & & & & & & & & 1.000 & 0.357 & $0.667^{*}$ \\
\hline Leaf $P$ & & & & & & & & & 1.000 & 0.241 \\
\hline Leaf N & & & & & & & & & & 1.000 \\
\hline
\end{tabular}

* indicates significance $5 \%$ probability level

Waterlogging tended to increase the internode length of sugarcane varieties; the highest increase was found in UP 9530 followed by BO 91 and CoS 767, whereas CoLk 12202 had the lowest. The average internode length of sugarcane varieties increased by $11 \%$ in waterlogging as compared to control. A significant waterlogging $\mathrm{x}$ variety interaction was detected for internode length (Table 1). However, the correlation between internode length during waterlogging and waterlogging tolerance was non significant (Table 3). Increase in internode length of sugarcane under waterlogging has been reported earlier (Anitha et al., 2016). High stalk extension rate and internode length helps the plant in securing oxygen when the usual supply of oxygen is restricted by flooding or submergence. It is suggested that varieties which maintain better shoot height and internode length yield better under flooding condition (Gomathi and Chandran, 2009).
A significant variation existed among sugarcane varieties for CSI value under waterlogging. The varieties with higher ranking for waterlogging tolerance like CoLk 94184, CoLk 12202, UP 9530, BO 91 showed high CSI value, while CoJ 64, lowest in waterlogging tolerance ranking, had lowest CSI value. A strong significant positive correlation ( $r=0.817$, Table 3 ) existed between CSI value and waterlogging tolerance, suggesting that CSI can be a criteria for distinguishing varieties for waterlogging tolerance. Waterlogging causes reduction in total cholorophyll content; high $\mathrm{CSI}$ value is an indicative of less reduction in chlorophyll content under waterlogging as compared to control. Varieties with high CSI value are relatively less chlorotic, and thereby maintain better photosynthetic rate during waterlogging. Earlier reports also indicate that in waterlogged condition, chlorophyll content reduces in sugarcane and tolerant varieties have relatively lesser reduction (Pandey et al., 2000; Gomathi et al., 2015). 

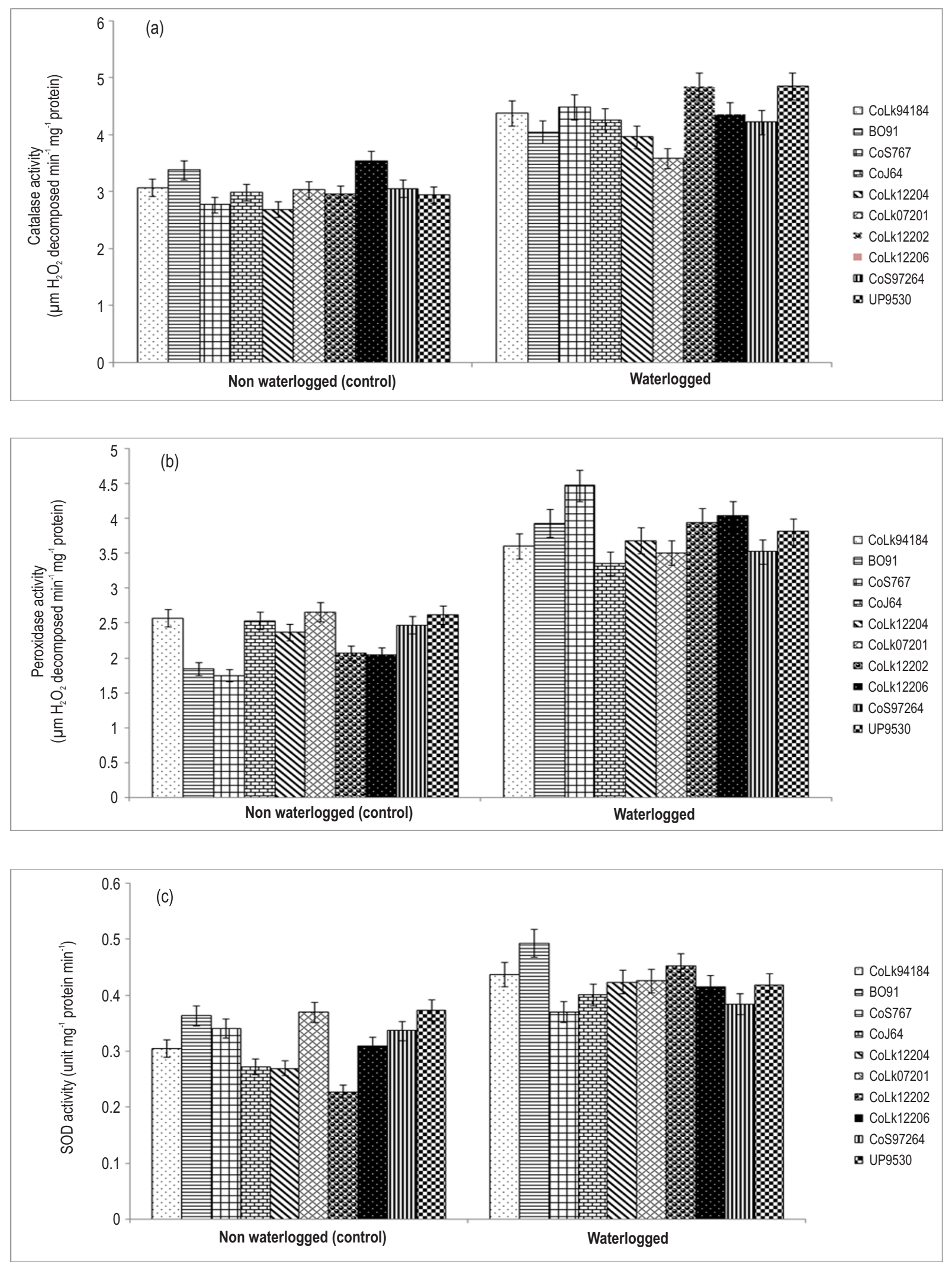

Fig. 1: Catalase (a), Peroxidase (b) and Superoxide dismutase (c) activities in leaves of sugarcane varieties under waterlogged and non waterlogged (control) conditions. Data are mean of three replicates $( \pm$ S.E.). 

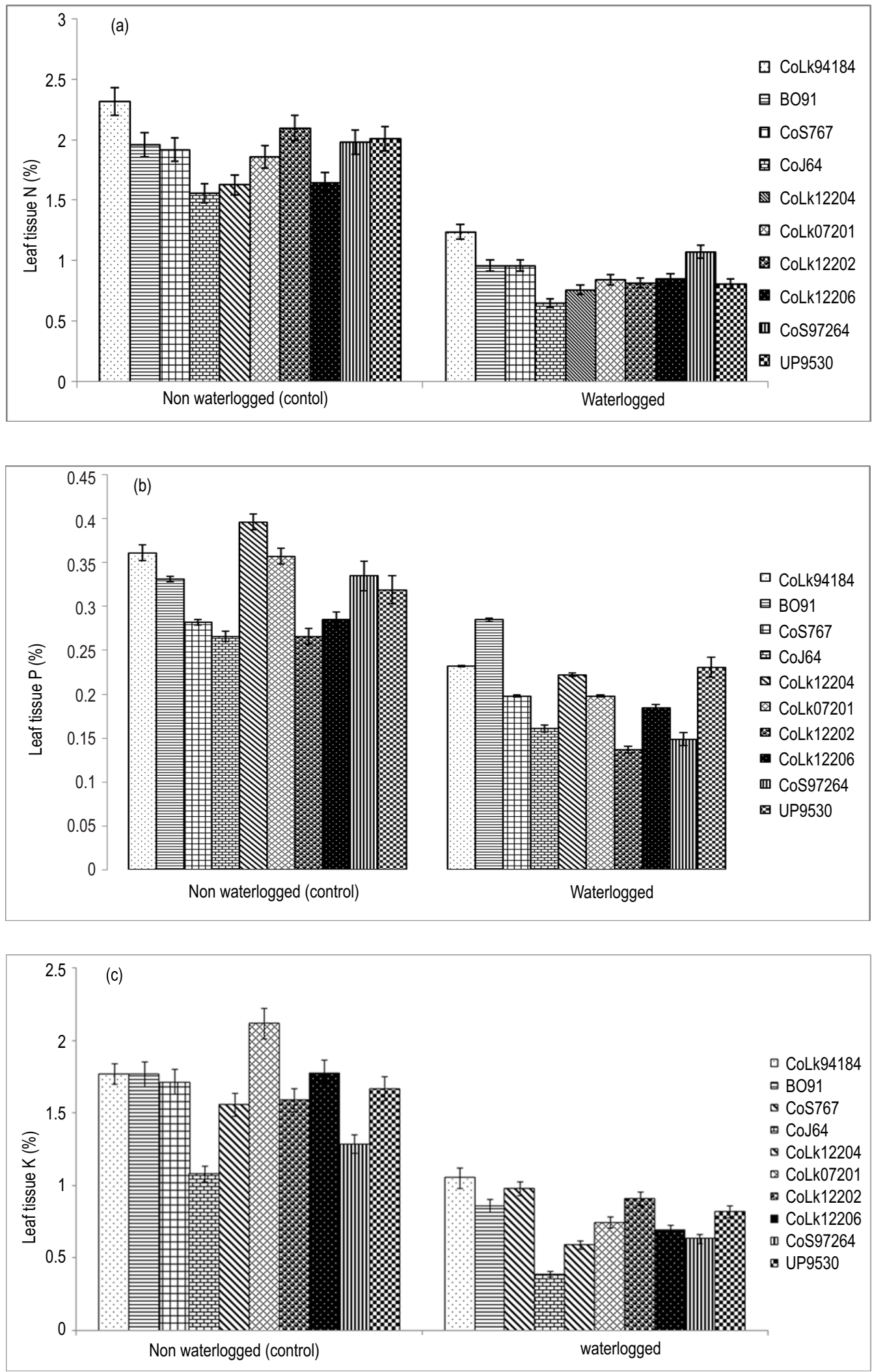

Fig. 2 : Leaf tissue nitrogen (a), phosphorus (b) and potassium (c) concentrations in sugarcane varieties under waterlogged and non waterlogged (control) conditions. Data are mean of three replicates ( \pm S.E.). 
Waterlogging induced a significant increase in antioxidant enzyme activity of catalase (CAT), peroxidase (POX) and superoxide dismutase (SOD). In control, varietal differences for CAT, POX and SOD activity were at par but significant differences were observed in waterlogging (Fig. 1). CAT activity increased by 18 to $65 \%$ in waterlogging compared to control (Fig. 1a). Increase in CAT activity in waterlogging was found more in varieties with higher ranking in waterlogging tolerance like UP 9530, CoLk12202 and CoS 767. Mean sum of square for waterlogging $x$ variety was found significant $(p<0.05)$ indicating that varieties differed for CAT activity in their response to waterlogging. The increase in POX activity due to waterlogging varied from 32 (CoLk 07201 ) to $155 \%$ (CoS 767) with an average increase of $70 \%$ (Fig. $1 \mathrm{~b})$. Mean sum of square for waterlogging, waterlogging $x$ variety for POX were found significant whereas it was non-significant for the variety. An increase of 9 to $99 \%$ in SOD activity was found due to waterlogging (Fig. 1c). In waterlogging, highest SOD activity was found in variety CoLk 12202 being at par with CoLk 12204, UP 9530 and CoLk 12206 while other varieties exhibited significantly lower values. A marginal positive correlation was found between CAT, POX and SOD activity and waterlogging tolerance (Table 3). Waterlogging induces the production of reactive oxygen species like superoxide, singlet oxygen, hydrogen peroxide and hydroxyl ions which are detrimental for plant growth. The SOD converts super oxide radicals into $\mathrm{H}_{2} \mathrm{O}_{2}$ (Alsher et al., 2002), which is further converted in to water and oxygen by the activity of catalase and peroxidase. The increase in the activity of these antioxidant enzymes help the plant to protect against oxidative damage by ROS. The increase in antioxidant enzymes have been reported in various crops under several abiotic stresses (Srivastava et al., 2012; Shalata et al., 2001; Demiral and Turkan, 2005).

Waterlogging caused a significant reduction in leaf $N, P$ and $\mathrm{K}$ content of sugarcane varieties (Fig. 2). The leaf $\mathrm{N}$ content in all sugarcane varieties under waterlogging decreased below the critical (1.80\%) deficiency level (Anderson and Bowen, 1990; McCray and Mylavarapu, 2010) and it ranged from 0.65 (CoJ 64) to $1.24 \%$ (CoLk 94184). The average leaf $\mathrm{N}$ content (across varieties) decreased by $53 \%$ in waterlogging over control (Fig. $2 a)$. The tolerant varieties maintained higher leaf $\mathrm{N}$ content than sensitive ones, but values were much below the critical deficiency level indicating that $\mathrm{N}$ was limiting factor for yield reduction for tolerant as well as sensitive varieties under waterlogging. The foliar application of nitrogenous compounds increase sugarcane yield in waterlogging substantiate this finding (Jain et al., 2016 ). The leaf $\mathrm{N}$ content in waterlogging showed a significant correlation $(r=0.683$, Table 3$)$ with internode length; this shows that the varieties with high leaf $\mathrm{N}$ had higher internode elongation. A positive correlation $(r=0.496$, Table 3$)$ was found between leaf $N$ content in waterlogging and waterlogging tolerance, but it was non significant. In waterlogged soils, restricted gas exchange and oxygen depletion leads to an increase in redox potential that promotes denitrification of nitrate ions, and thereby resulting in deficiency of nitrogen in plant (Hamonts et al., 2013; Herzog et al., 2016).
In earlier work, a decrease of $25.2 \%$ in leaf $\mathrm{N}$ content has been reported in waterlogging for sugarcane (Gomathi et al., 2010). The leaf $P$ content of all varieties was low under waterlogging as compared to control, however the values were above critical $(0.19 \%)$ deficiency level (Anderson and Bowen, 1990; McCray and Mylavarapu, 2010), except for varieties CoJ 64, CoLk 07201 and CoS 97264 which had values lower than critical deficiency level (Fig. 2b). Thus, P does not seems to be a limiting factor for sugarcane yield under waterlogging stress. The tolerant varieties showed relatively higher leaf $P$ content than sensitive one but the correlation between leaf $P$ content in waterlogging and waterlogging tolerance was non significant. Waterlogging decreases $P$ content because of oxygen deficiency and impaired root functioning (Trought and Drew, 1980) and lack of energy for ion uptake (Barrett- Lennard et al., 1990). Similar to our results, decline in $P$ content have been reported for waterlogged wheat and sensitive varieties of wheat have lower $P$ content than tolerant varieties (Huang et al.,1995; Singh and Setter, 2017). The leaf $K$ content under waterlogging dropped below the critical $(0.90 \%)$ deficiency level (Anderson and Bowen, 1990; McCray and Mylavarapu, 2010), except for varieties CoLk 94184, CoS 767 and CoLk 12202 (Fig. 2c). In waterlogging, the leaf $\mathrm{K}$ content of tolerant variety, CoLk $94184(1.058 \%)$ was about 2.5 fold higher than sensitive variety, CoJ64 (0.394\%) which indicates marked genetic differences for this nutrient. A strong positive correlation was found between leaf $K$ content in waterlogging and waterlogging tolerance $(r=0.897$, Table 3$)$. This indicates that varieties with high $\mathrm{K}$ uptake efficiency perform remarkably better under waterlogged condition. Further, leaf $\mathrm{K}$ content was also found to be significantly correlated with CSI and leaf $\mathrm{N}$ content in waterlogging with $\mathrm{r}$ values of 0.833 and 0.667 , respectively (Table 3 ). Thus, high leaf $\mathrm{K}$ content may be an important selection indices for waterlogging tolerance. Decrease in $\mathrm{K}$ in sugarcane varieties under waterlogging is in agreement with the previous report on wheat (Singh and Setter, 2017). It is also suggested that application of potassium along with $\mathrm{N}$ and $\mathrm{P}$ improves the tolerance to waterlogging (Cong et al., 2009).

The results of the present study concluded that sugarcane variety CoLk 94184 was most tolerant to waterlogging conditions and sugarcane variety CoJ64 as least tolerant. The stalk growth rate, $\mathrm{CSI}$ and leaf $\mathrm{K}$ content were considered as important selection criteria for waterlogging conditions.

\section{Acknowledgment}

The author thank the Director, ICAR- Indian Institute of Sugarcane Research, Lucknow for funding and facilities provided for the present work.

\section{References}

Alsher, R.G., N. Erturk and L.S. Heath: Role of superoxide dismutases (SODs) in controlling oxidative stress. J. Exp. Bot., 53, 13311341(2002).

Anderson, D.L. and J.E. Bowen: Sugarcane Nutrition. Potash and Phosphate Institute, Atlanta, GA (1990). 
Anitha, R., P.C. Nirmala Mary and R.S. Purushothaman: Biometric and physiological characteristics of sugarcane ratoon under waterlogging condition. Plant Arch., 16, 105-109 (2016).

Arnon, D.I.: Copper enzymes in isolated chloroplasts: Polyphenol oxidase in Beta vulgaris. Plant Physiol., 24, 1-15 (1949).

Bailey-Serres, J. and LACJ. Voesenek: Flooding stress: Acclimations and genetic diversity. Annu. Rev. Plant Biol., 59, 313-339 (2008).

Barrett-Lennard, E.D., N. Davidson and R. Galloway: Plant growth and survival in saline, waterlogged soils. WA J. Agric., 31, 56-57 (1990).

Beers, R.F. and Jr. I.W. Sizer: A spectrophotometric method for measuring the breakdown of hydrogen peroxide by catalase. $\mathrm{J}$. Biol. Chem., 95, 133-140(1952).

Begum, M.K., M.R. Alam and M.S. Islam: Adaptive mechanisms of sugarcane genotypes under flood stress condition. W. J. Agric. Sci., 1, 56-64 (2013)

Beyer, W.F. and Jr. I. Fridovich: Assaying for superoxide dismutase activity: Some large consequences of minor changes in conditions. Anal. Biochem., 161, 559-566 (1987).

Bradford, M.M.: A rapid and sensitive method for the quantization of microgram quantities of protein utilizing the principle of protein-dye binding. Anal. Biochem., 72, 248-254(1976).

Cong, Y., Y. J. Li, C.J. Zhou, C. S. Zou, X.K. Zhang, X. Liao and C.L. Zhang: Effect of application of nitrogen, phosphorus and potassium fertilizers on yield in rapeseed (Brassica napus L.) under the waterlogging stress. Plant Nutr. Fert. Sci., 15, 1122-1129 (2009).

Demiral, T. and I. Türkan: Comparative lipid peroxidation, antioxidant defence systems and proline content in roots of two rice cultivars differing in salt tolerance. Environ. Exp. Bot., 53, 247-257 (2005).

Dodd, K., C.N. Guppy, P.V. Lockwood and I.J. Rochester: Impact of waterlogging on the nutrition of cotton (Gossypium hirsutum L.) produced in sodic soils. Crop Pasture Sci., 64, 816-824 (2013).

Dwivedi, R.S.: Adaptability mechanism of sugarcane cultivars to abiotic stresses. In: Proceedings of Summer School on Advances in Sugarcane Production Technology at ICAR-Indian Institute of Sugarcane Research, Lucknow, Uttar Pradesh, pp. 42-45 (2000).

Fiske, C.H. and Y. Subba Row: The colorimetric determination of phosphorus. J. Biol. Chem., 66, 375-400 (1925).

Garnaczarskam M., W. Bednarski and I. Morkunasi: Re-aeration induced oxidative stress and oxidative defence in hypoxically pretreated lupine roots. J. Plant Physiol., 161, 415-22 (2004).

Gilbert, R. A., C.R. Rainbolt, D.R. Morris and J.M. McCray: Sugarcane growth and yield responses to a 3-month summer flood. Agric Water Manag., 95, 283-291(2008).

Gilbert, R.A., C.R. Rainbolt, D.R. Morris and A.C. Bennett: Morphological responses of sugarcane to long term flooding. Agron. J., 99, 1622-1628 (2007).

Glaz and S. E. Lingle: Flood duration and time of flood onset effects on recently planted sugarcane. Agron. J., 104, 575-583 (2012).

Gomathi, R. and K. Chandran: Effect of waterlogging on growth and yield of sugarcane clones. Sugarcane Breeding Institute (SBI-ICAR). Quarterly News Letter, 29, 1-2 (2009).

Gomathi, R., K. Chandran, P. N. Gujuraja Rao and P. Rakkiyappan: Effect of waterlogging in sugarcane and its management. Published by The Director, Sugarcane Breeding Institute SBIICAR Coimbatore, Extension publication No. 185 (2010).

Gomathi, R., P.N. Gururaja Rao, K. Chandran and A. Selvi: Adaptive responses of sugarcane to waterlogging stress: An overview. SugarTech., 17, 325-338 (2015).

Gomez, K.A. and A.A. Gomez: Statistical procedures for agriculture research. Wiley, New York (1984).
Greenway, H., W. Armstrong and T.D. Colmer: Conditions leading to high $\mathrm{CO}_{2}$ in waterlogged-flooded soils and possible effects on root growth and metabolism. Ann. Bot., 98, 9-32 (2006).

Hamonts, K., T.J. Clough, A. Stewart, P.W. Clinton, A.E. Richardson, S.A. Wakelin and M. O'Callaghan: Effect of nitrogen and waterlogging on denitrifier gene abundance, community structure and activity in the rhizosphere of wheat. FEMS Microbiol. Ecol., 83, 568-584 (2013).

Herzog, M., G.G. Striker, T.D. Colmer and O. Pedersen: Mechanisms of waterlogging tolerance in wheat $-A$ review of root and shoot physiology. Plant Cell Environ., 39, 1068-1086 (2016).

Hidaka, T. and M. A. Karim: Flooding tolerance of sugarcane in relation to growth, physiology and root structure. South Pacific Studies, 28 , 9-22 (2007).

Huang, B., J.W. Johnson, D.S. NeSmith and D.C. Bridges: Nutrient accumulation and distribution of wheat genotypes in response to waterlogging and nutrient supply. Plant Soil, 173, 47-54 (1995).

Jackson, M.B. and M.C. Drew: Effects of flooding on growth and metabolism of herbaceous plants. In: Flooding and Plant Growth (Ed.: T.T. Kozlowski). Academic Press, Inc; Waltham, MA, USA. pp. 47-128 (1984).

Jain, R., S.P. Singh, A. Singh, S. Singh, A. Chandra and S. Solomon: Response of foliar application of nitrogen compounds on sugarcane grown under waterlogging stress. Sugar Tech., 18, 433-436 (2016).

Jaiphong, T., J. Tominaga, K. Watanabe, M. Nakabaru, H. Takaragawa, R. Suwa and Y. Kawamitsu: Effects of duration and combination of drought and flood conditions on leaf photosynthesis, growth and sugar content in sugarcane. Plant Prod. Sci., 19, 427-437(2016).

Jaiphong, T., J. Tominaga, K. Watanabe, R. Suwa, M. Ueno and Y. Kawamitsu: Changes in photosynthesis, growth and sugar content of commercial sugarcane cultivars and Erianthus under flood conditions. Plant Prod. Sci., 20, 126-135 (2017).

Lindner, R.C.: Rapid analytical methods for some of the more common inorganic constituents of the plant tissues. Plant Physiol., 19, 7689 (1944).

Manoharan, M.L., K. Duraisamy, S.V. Krishnamurthy, H. Vijayaraghan and K. Muthkrishnan: Performance sugarcane varieties in waterlogged condition. Maharastra Sugar, 15, 39-45 (1990).

McCray, J. M. and R. Mylavarapu: Sugarcane nutriาent management using leaf analysis. Gainesville: University of Florida Institute of Food and Agricultural Sciences. SS-AGR-335. http:// edis. ifas. ufl. edu/ag345 (2010).

Pandey, O.P., A. Kumari and H. Haque: NAD- alcohol dehydrogenase and superoxide dismutase activity in Zea mays under hypoxia and post-hypoxia stress regime. Plant Biol., 27, 71-73 (2000).

Setter, T.L., I. Waters, H. Khabaz- Saberi, G. McDonald and B. Biddulph: Screening for waterlogging tolerance of crop plants. In: $8^{\text {th }}$ conference of the International Society for Plant Anaerobiosis, Perth, WesternAustralia (2004).

Shalata, A., V. Mittova, M. Volokita, M. Guy and M. Tal: Response of the cultivated tomato and its wild salt-tolerant relative Lycopersicon pennellii to salt-dependent oxidative stress: The root antioxidative system. Physiol. Plant., 112, 487-494 (2001).

Siegel, B.Z. and A.W. Galston: The peroxidase of Pisum sativum. Plant Physiol., 42, 221-226 (1976).

Singh, S.P. and T.L. Setter: Effect of waterlogging on element concentrations, growth and yield of wheat varieties under farmer's sodic field conditions. Proc. Natl. Acad. Sci. India Sect. B Biol. Sci., 87, 513-520 (2017)

Solomon, S., R. Jain, A. Chandra, S.K. Shukla, R. J. Lal, V.K. Venugopalan, K. Nitya, S. K. Holkar, M.R. Singh, B. Prakash and M. Ashfaque: Sugarcane: A voyage from sett to sweeteners. Indian Institute of 
Sugarcane Research, Lucknow, Uttar Pradesh, pp. 4-7 (2014).

Srivastava, H.M.: Improved sugarcane varieties and their characteristics. In: Proceedings of Summer School on Advances in Sugarcane Production Technology at ICAR-Indian Institute of Sugarcane Research, Lucknow, Uttar Pradesh, pp. 20-26 (2000).

Srivastava, S., A.D. Pathak, P.S. Gupta, A.K. Shrivastava and A.K Srivastava: Hydrogen peroxide-scavenging enzymes impart tolerance to high temperature induced oxidative stress in sugarcane. J. Environ. Biol., 33, 657-661 (2012)

Trought, M.C.T. and M.C. Drew: The development of waterlogging damage in wheat seedlings (Triticum aestivium L.) II. Accumulation and redistribution of nutrients by the shoot. Plant Soil, 56, 187-199 (1980).

Viator, R. P., Jr. P. M. White, A. J. Hale and H. L. Waguespack: Screening for tolerance to periodic flooding for cane grown for sucrose and bioenergy. Biomass Bioenergy, 44, 56-63 (2012).

Zeng, F., L. Shabala, M. Zhou, G. Zhang and S. Shabala: Barley responses to combined waterlogging and salinity stress: Separating effects of oxygen deprivation and elemental toxicity. Front Plant Sci., 4, 313 (2013.). 